\title{
FINE STRUCTURAL CHANGES IN HAEMODYNAMIC PULMONARY OEDEMA
}

\author{
William H. Noble, M.D., Dip.anaes. (ToR.), F.R.C.P.(c), \\ Kalman KovaCS, M.D., PH.D., D.SC., F.R.C.P.(C), AND \\ J. CoLIN KAY, A.I.M.L.T.(ENG.)
}

\begin{abstract}
INTRODUCTION
Previous studues indicated that in gross pulmonary oedema, atelectasis and/or intra-alveolar fluid accumulation are associated with hypoxia. However no major alteration in gas exchange can be detected in early pulmonary oedema $\left(\mathrm{ETV}_{\mathrm{L}}<\right.$ $60 \%$ above control). It was also noted that continuous positive pressure ventilation (CPPV) immediately reduced shunting of blood through grossly oedematous lungs, but at the same time neither suppressed the rate of oedema formation nor led to removal of fluid from the lung. ${ }^{1}$

Recently a double indicator technique $\left(\mathrm{ETV}_{\mathrm{L}}\right)$ was developed in our laboratory which allowed repeated accurate measurements of the amount of fluid accumulation in the lungs. ${ }^{2,3} \mathrm{By}$ using this new technique an attempt was made to correlate gas exchange, the amount of pulmonary fluid accumulation, and both light and electron microscopic features of the lung in dogs with a haemodynamic type of pulmonary oedema due to circulatory overload caused by dextran administration. The effects of CPPV on these various parameters were also investigated. We describe here the results of these experiments.
\end{abstract}

\section{Methods}

Three mongrel dogs weighing $15-30 \mathrm{~kg}$ were anaesthetized with intravenous pentobarbitone and a tracheostomy was performed. The dogs were allowed to breathe air spontaneously while lying supine. Femoral arterial and venous catheters were inserted for pressure monitoring and drug infusion. A flexible silastic injection catheter with an inner thermistor catheter (YSI no. 511) was floated into the pulmonary artery from the external jugular vein. Placement of the catheter tip just inside the pulmonary artery was determined by pressure monitoring. A special catheter for detecting electrical conductivity and temperature of blood was passed down the internal carotid artery to the arch of the aorta.

The double indicator dilution method to quantify pulmonary oedema $\left(\mathrm{ETV}_{\mathrm{L}}\right)$ has been described in detail..,3 For each determination of ETV $_{\mathrm{L}}, 5 \mathrm{ml}$ of 3 per cent saline at room temperature was injected into the pulmonary artery while recording aortic blood conductivity and temperature. From these recordings cardiac output (QT), central blood volume ( $\mathrm{CBV} \mathrm{Na}$ ), and the amount of pulmonary oedema $\left(\mathrm{ETV}_{\mathrm{L}}\right)$ were calculated.

Departments of Anaesthesia and Pathology, St. Michael's Hospital and University of Toronto, Toronto, Ontario, Canada.

Canad. Anaesth. Soc. J., vol. 21, no. 3, May 1974 
TABLE I

VALUES OF 1 Dog

\begin{tabular}{lcccc}
\hline & Control & $\begin{array}{c}\text { Early } \\
\text { oedema }\end{array}$ & $\begin{array}{c}\text { Gross } \\
\text { oedema }\end{array}$ & CPPV \\
\cline { 2 - 5 } & 6.5 & 7.5 & 12 & 19.7 \\
$\mathrm{ETV}_{\mathrm{L}} \mathrm{ml} / \mathrm{kg}$ & 100 & 88.5 & 43.5 & 69.5 \\
$\mathrm{PaO}_{2}$ torr & 2.0 & 4.3 & 4.1 & 1.7 \\
$\mathrm{QT} \mathrm{I} \mathrm{L} / \mathrm{min}_{\mathrm{CBV} \mathrm{Na} \mathrm{ml}}$ & 223 & 350 & 290 & 120 \\
$\mathrm{PA}$ press. $\mathrm{mm} \mathrm{Hg}$. & 13 & 35 & 45 & 43 \\
\hline
\end{tabular}

Arterial blood gases were corrected to the dog's temperature with a Severinghaus blood gas calculator. ${ }^{4}$

The conduct of the experiment follows. Control measurements were taken before and after placing the dogs on a Harvard respirator. A thoractomy in the 5th right intercostal space allowed lung biopsies from the lung edge without traumatizing other lung tissue. Biopsies were taken by first clamping the area to be biopsied with a Pott's clamp and then cutting a small wedge of tissue. The clamp was left on to prevent gas leaks and in a manner which minimized lung distortion. Biopsies were taken from the same gravitational plane to reduce blood and gas volume differences due to gravity.

After a control biopsy was taken, 10 per cent dextran (molecular weight 40,000, Pharmacia, Canada) in normal saline was infused continuously while monitoring ETV $_{\mathrm{L}}, \mathrm{Q}_{\mathrm{T}}, \mathrm{CBV} \mathrm{Na}$ and blood gases.

A second biopsy was taken in early oedema $\left(\operatorname{ETV}_{\mathrm{L}} 15-60\right.$ per cent above control). A third biopsy was taken in gross oedema and after the $\mathrm{PaO}_{2}$ fell $\left(\mathrm{ETV}_{\mathbf{L}}\right.$ 85-200 per cent above control).

Continuous positive pressure ventilation was then applied by placing the expiratory tubing under $15 \mathrm{~cm} \mathrm{H}_{2} \mathrm{O}$. A final biopsy was taken after CPPV was applied and $\mathrm{ETV}_{\mathrm{I}}$ and blood gas measurements made.

For light microscopy, lung tissue was fixed in 10 per cent neutral formalin and embedded in paraffin. Sections of 4-6 $\mu$ thickness were stained with haematoxylinphloxine-saffron. and with the PAS technique.

For electron microscopy pieces of lung tissue were fixed in 2.5 per cent glutaraldehyde in $0.15 \mathrm{M}$ Sorensen's buffer immediately after their removal; postfixed in 1 per cent osmium tetroxide in Millonig's phosphate buffer, dehydrated in graded ethanol and embedded in epoxy resin. Thick sections were cut with a Porter Blum MT2 ultramicrotome, stained with toluidine blue and examined by light microscopy. From selected areas ultrathin sections were cut, stained with uranyl acetate and lead citrate and investigated with a Philips 300 electron microscope.

\section{Results}

In every dog the infused dextran increased QT, CBV Na and pulmonary artery pressure immediately (Table I).

With increased perfusion $\mathrm{PaO}_{2}$ rose, but as $\mathrm{ETV}_{\mathrm{I}}$, increased $\mathrm{PaO}_{2}$ fell slowly at 
TABLE II

Mean Values of 3 Dogs \pm 1 S.D.

\begin{tabular}{|c|c|c|c|c|}
\hline & Control & $\begin{array}{c}\text { Early } \\
\text { oedema }\end{array}$ & $\begin{array}{c}\text { Gross } \\
\text { oedema }\end{array}$ & CPPV \\
\hline $\mathrm{ETV}_{\mathrm{L}}$ & $\begin{array}{r}6.09 \\
\pm 0.29\end{array}$ & $\begin{array}{r}7.25 \\
\pm 0.25\end{array}$ & $\begin{array}{r}13.5 \\
\pm 1.9\end{array}$ & $\begin{array}{r}17.5 \\
\pm 1.8\end{array}$ \\
\hline $\mathrm{PaO}_{2}$ & $\begin{array}{c}85 \\
\pm 9.9\end{array}$ & $\begin{array}{r}82.2 \\
\pm 6.3\end{array}$ & $\begin{array}{r}47.2 \\
\pm 7.5\end{array}$ & $\begin{array}{l}69.25 \\
\pm .25\end{array}$ \\
\hline
\end{tabular}

first and rapidly later. CPPV dramatically increased $\mathrm{PaO}_{2}$ but did not reduce the rate of formation nor remove pulmonary oedema (Table II). $\mathrm{pH}$ and $\mathrm{PcO}_{2}$ did not change dramatically.

Light microscopy was not of much value in the early phases of pulmonary oedema, as interstitial oedema cannot be detected by this technique. ${ }^{5}$ When gross oedema was evident, the perivascular and peribronchial connective tissue seemed to be swollen and the capillaries distended and filled with blood. The alveoli appeared to be dilated and contained a pink, slightly acidophilic granular material, erythrocytes and a few polymorphonuclear leucocytes. There was also some evidence of alveolar collapse in some places. Histologically there were no marked changes on application of CPPV. However, collapse of lung seemed to be of a lesser degree. There was some re-expansion of the alveoli.

By electron microscopy ultrastructural features of the lungs of normal dogs did not differ from those reported by previous authors ${ }^{5,6}$ and will not be described in detail here. Suffice it to say that the alveoli were open and no oedema was present. The endothelial and epithelial cells were easily recognized. The endothelial cells were continuous and numerous pinocytotic vesicles were found in their cytoplasm. Type II pneumocytes contained cytoplasmic lamellar inclusions. The interstitial spaces were well developed and contained bundles of collagen fibres, elastic tissue, a few fibroblasts and an occasional mast cell (Figs. I and 2).

In the early phases of oedema (Fig. 3) fluid accumulated in the interstitium. The interstitium was wider and looser than in the normal lungs. The collagen fibres were separated and in some places disrupted. There were no changes in the alveoli at this stage. The endothelial cells were focally swollen and blebs of various sizes were formed in their cytoplasm. There were no ruptures along the capillary walls and gaps could not be detected. The epithelial lining seemed to be intact. The number of lamellae in the cytoplasmic inclusion bodies of type II pneumocytes appeared to be decreased.

In gross pulmonary oedema (Figs. 4,5 and 6) many alveoli were dilated and contained fibrin fibres, polymorphonuclear leucocytes, red blood cells, platelets and an electron lucent material obviously corresponding to plasma fluid. The interstitium was much wider than normal and among the separated and disrupted collagen fibres, platelets, red and white blood cells and fibrin were detected. Mast cells were swollen and degranulated. The endothelial cells were swollen and vacuolated. The pinocytotic vesicles were difficult to define. Large blebs were observed in the cytoplasm. In some places the endothelial cells were lifted away 


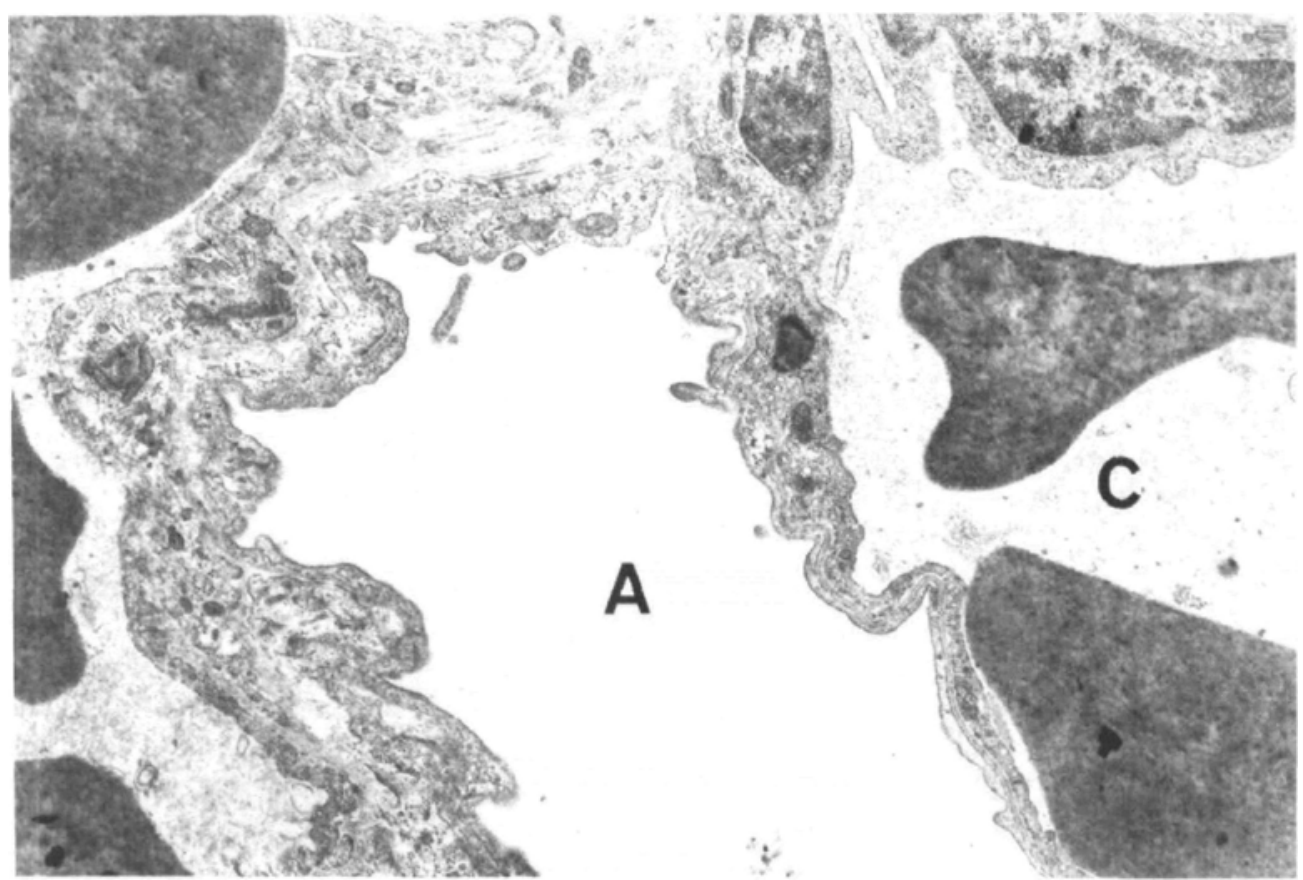

FIGURE 1. Control lung exhibiting the characteristic features (A: alveolar lumen; $C$ : capillary). $\times 13,760$.

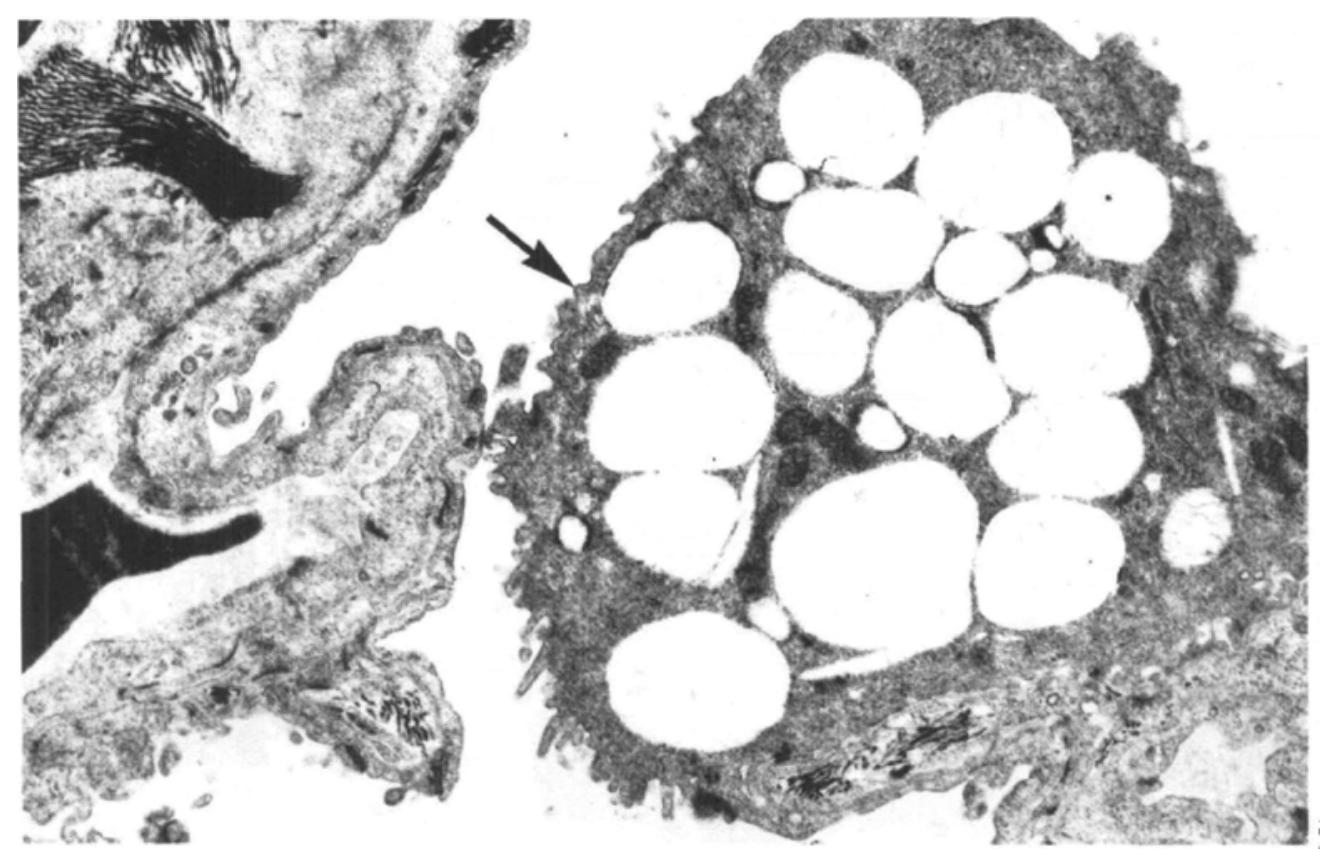

Frcure 2. Type II pneumocyte (arrow) in normal lung. $\times 11,310$. 


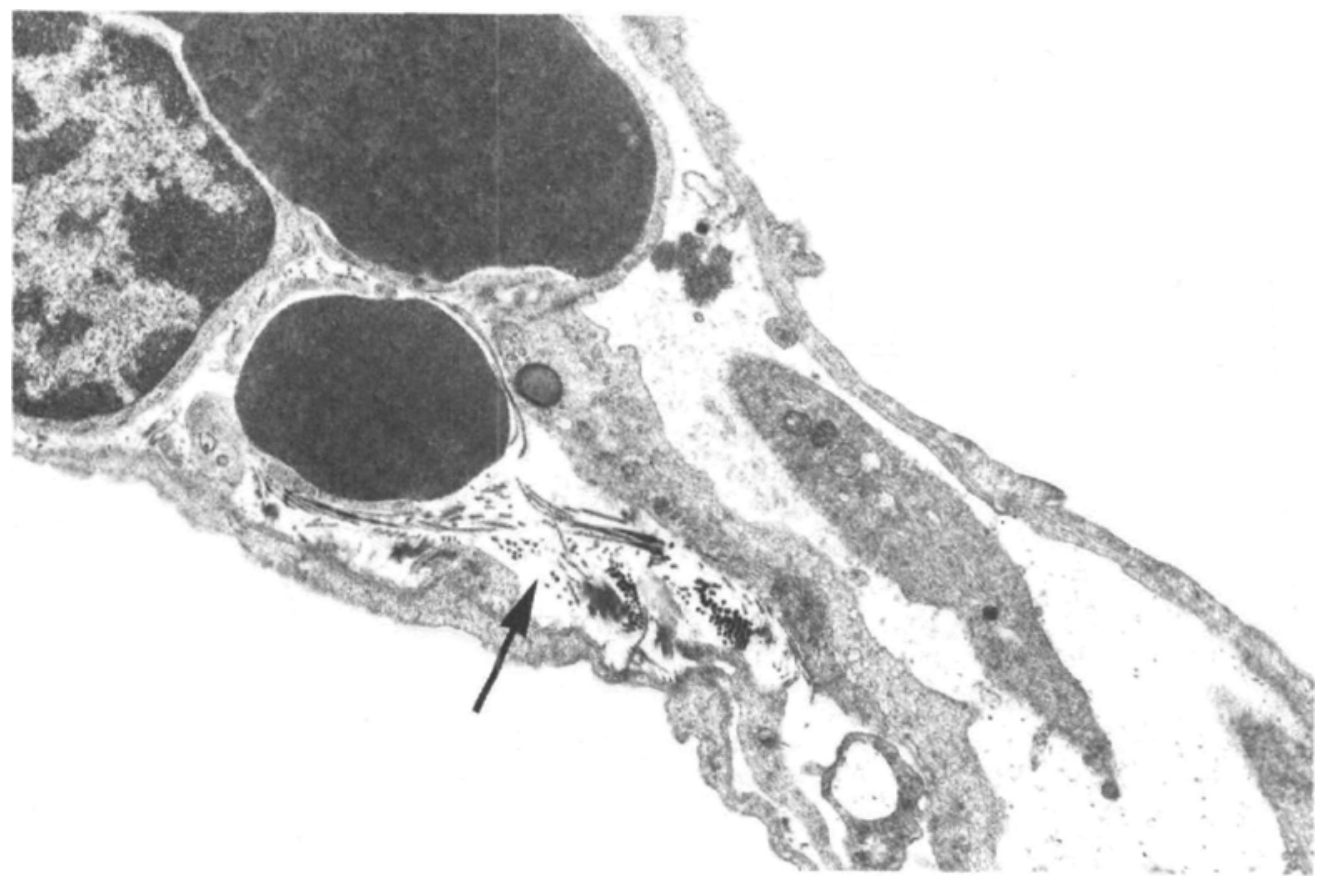

Frgure 3. Alterations in the interstitium (arrow) in early phase of oedema. $\times 11,310$.

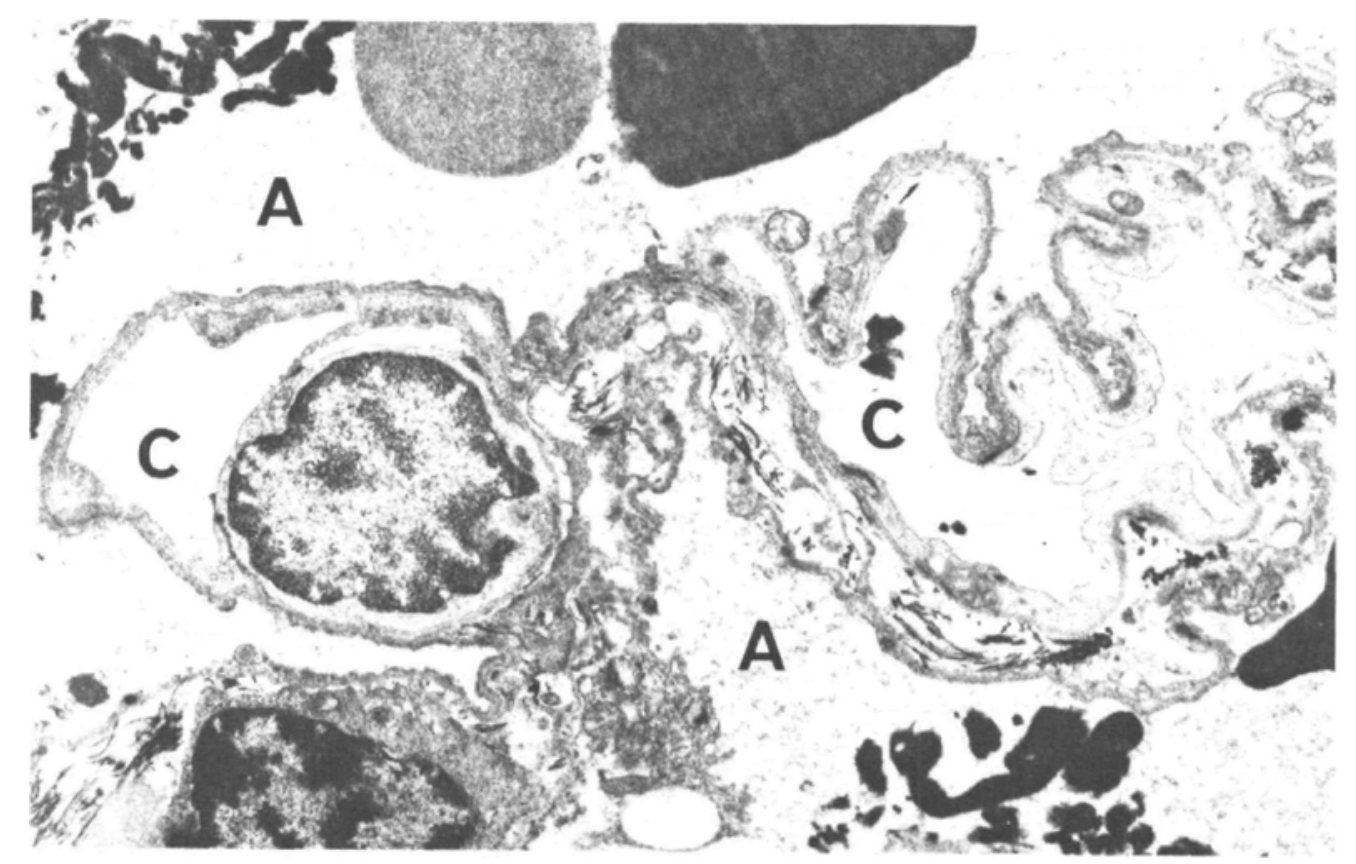

Figure 4. Advanced pulmonary oedenaa (A: alveolar lumen; C: capillary). $\times 7,410$. 


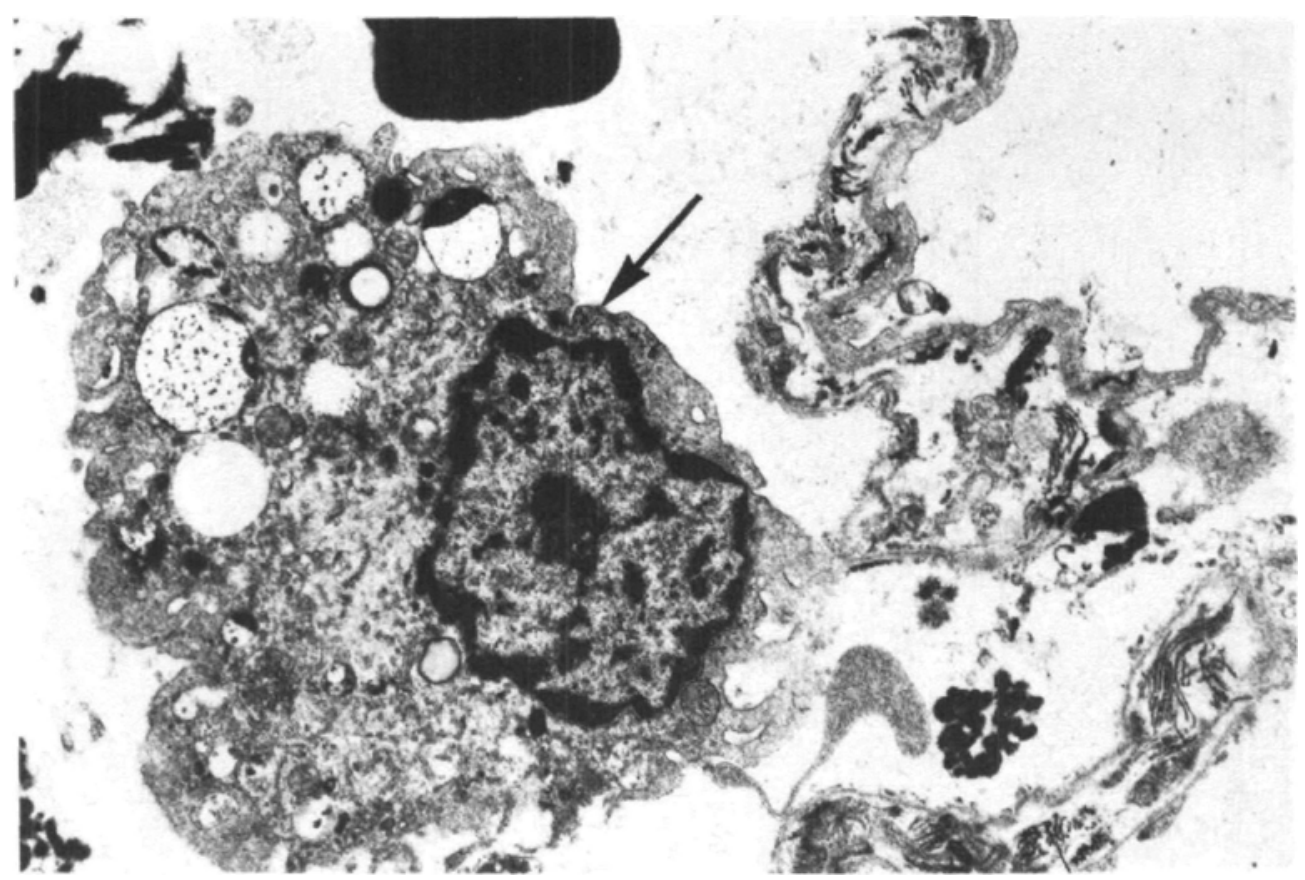

FrguRE 5. Advanced pulmonary oedema. Abnormal type II pneumocyte (arrow). $\times 9,220$.

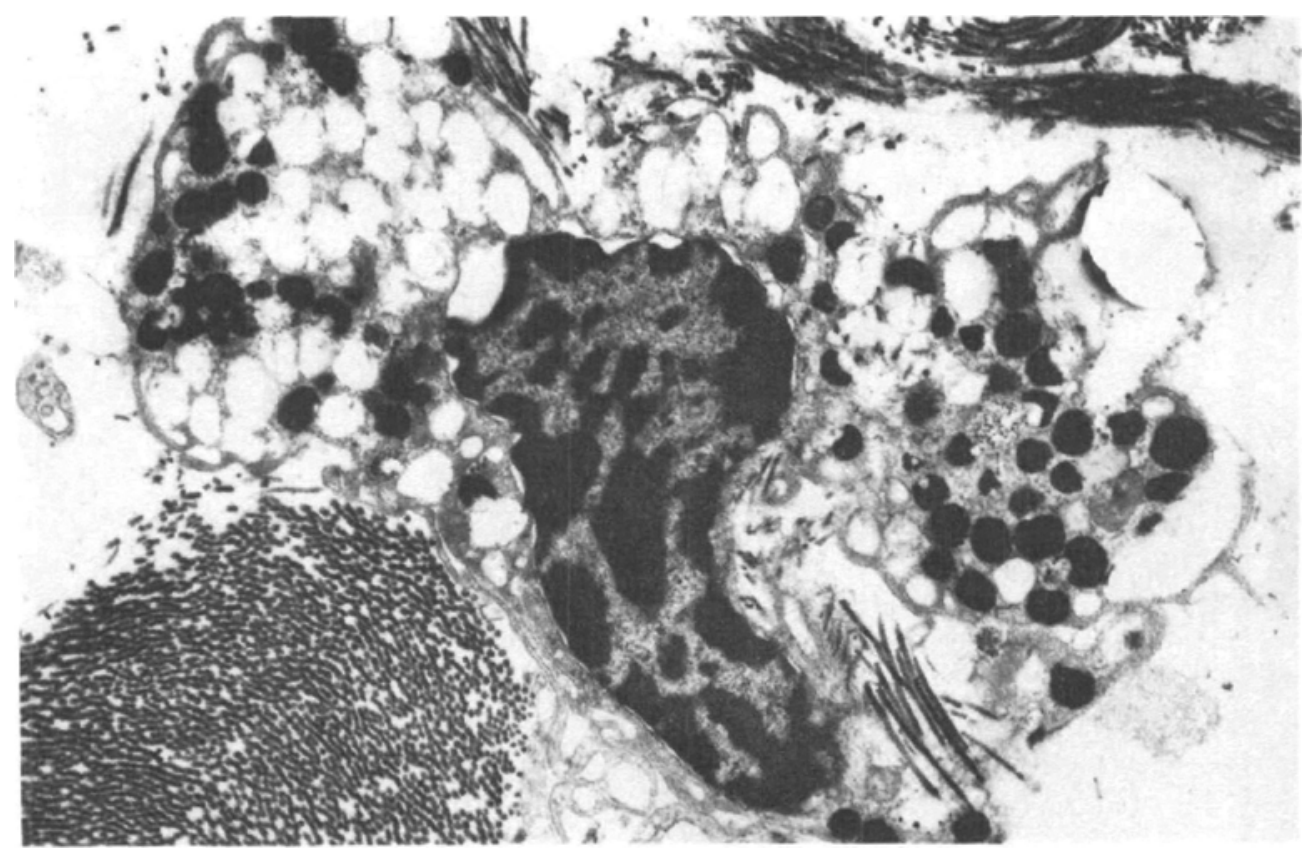

Figure 6. Mast cell showing degranulation in the interstitium. Advanced pulmonary oedema. $\times 9,220$. 
from the underlying basement membrane. This separation was due to fluid accumulation and resulted in a blister-like transformation of the endothelial cells. Their protrusion into the capillary lumen subsequently led to rupture and complete detachment of the endothelium, leaving behind a naked basement membrane directly exposed to blood flow. The basement membrane was well preserved. The epithelial cells exhibited only focal injury and only in the late and extensive phases. Some type II pneumonocytes seemed to be swollen. Others transformed into dark cells. This latter alteration was interpreted as indicating a severe, probably irreversible damage. The lamellar inclusions characteristic of the cytoplasm of normal type II pneumocytes disappeared from some cells and were replaced by empty spaces partly filled with a very dense, granular material.

After CPPV (Figs. 7 and 8) oedema was still apparent in the alveoli although the changes seemed to be more prominent in the interstitium. The alveolar lumen focally still contained erythrocytes, polymorphonuclear leucocytes, platelets and fibrin fibres. Most of the alveoli, however, were not filled with fluid and were encroached upon by the surrounding oedematous tissues. The separation and focal disruption of collagen fibres was still evident. The endothelium was focally absent and blister formation was still conspicuous.

\section{DisCUSSION}

Early interstitial pulmonary oedema $\left(\mathrm{ETV}_{\mathrm{r}}<60 \%\right.$ above control) is accompanied by a slight reduction of arterial oxygenation. At the same time pulmonary oedema is not detectable by auscultation and yet electron microscopy reveals marked widening of the interstitium with accumulation of fluid. In gross oedema, which is clinically detectable, alveoli are fluid filled. This accounts for the fall in FRC, increased shunt and markedly decreased arterial oxygenation at this stage. By electron microscopy severe injury of endothelial cells is evident. The surfactant producing type II pneumocytes also seem to be damaged but further work is needed to clarify their role in the genesis and evolution of dextran-induced pulmonary oedema. The mechanism of oedema formation also remains to be elucidated. The pinocytotic vesicles in the cytoplasm of endothelial cells did not appear to be increased in number or size as oedema progressed. Since marker substances were not used in the present studies we could not locate the site of increased permeability.

In the present study mast cells were found to be degranulated in gross pulmonary oedema. Haas and Bergofsky ${ }^{7}$ demonstrated that mast cells are degranulated in vivo during alveolar hypoxia and that there is a rise of pulmonary resistance during hypoxia, which is proportional to the amount of histamine released. This would suggest that hypoxia occurring in gross pulmonary oedema has led to degranulation of mast cells. In a previous study we found a close relation between the fall in arterial oxygenation and the onset of rapidly accumulating pulmonary oedema (alveolar phase). ${ }^{1}$ This would also suggest that histamine or other humoral substances released from the mast cells may increase capillary permeability and play some part in the causation of the alveolar phase of oedema.

CPPV dramatically improved oxygenation in all dogs but at the same time did 


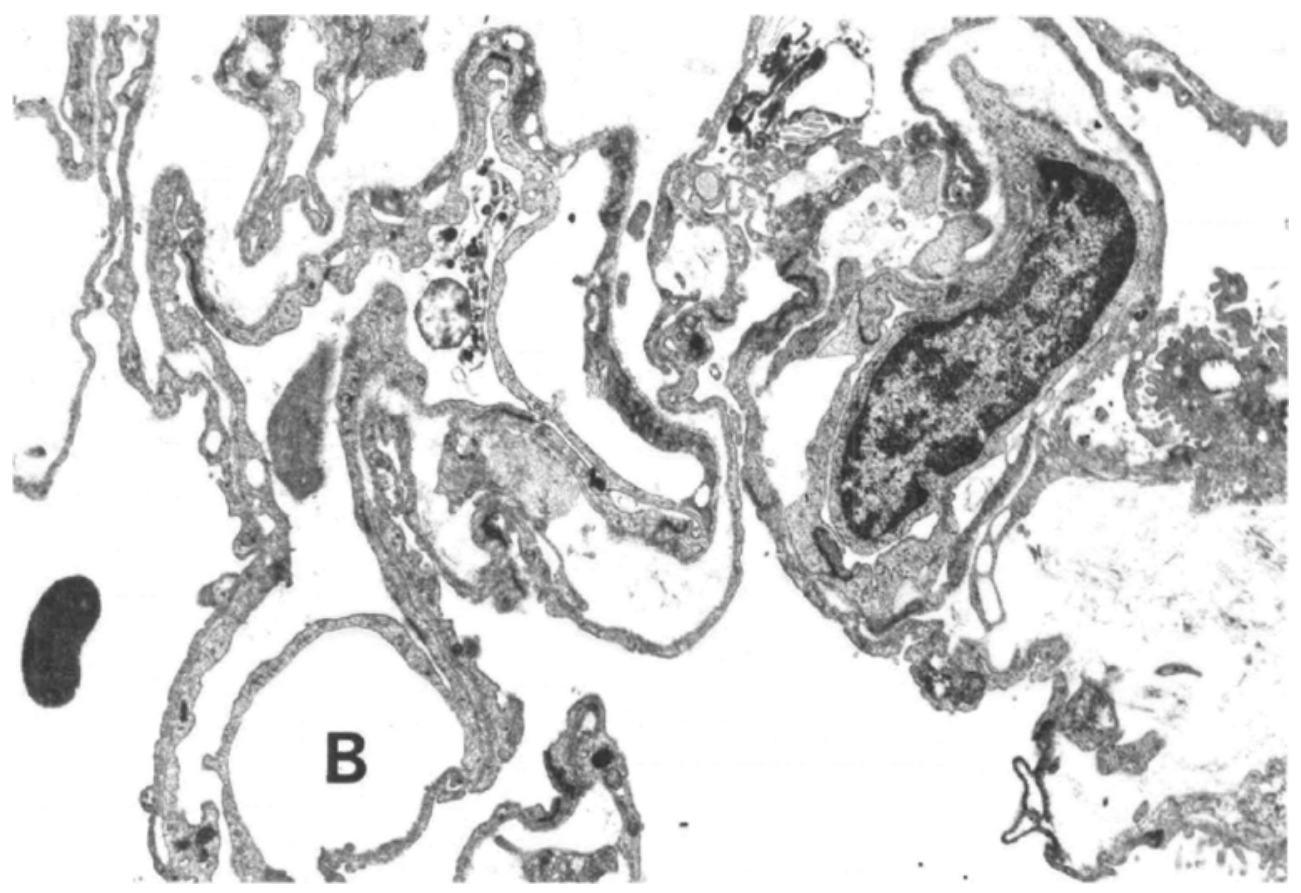

Figure 7. Lung after CPPV. Blister formation (B) is still conspicuous, $\times 7,410$.

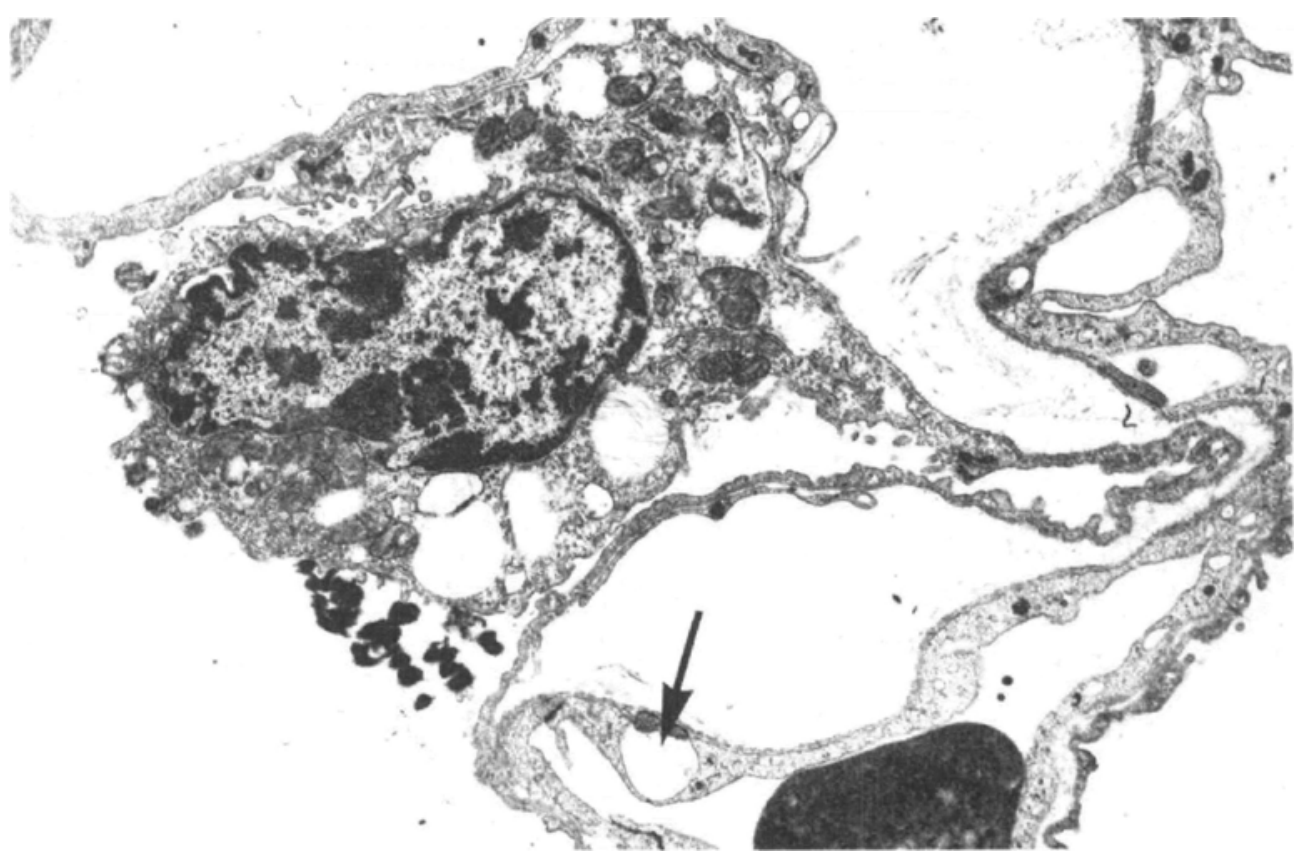

Figure 8. Lung after CPPV. Blister formation (arrow) is apparent. A type II pneumocyte is also seen. $\times 9,220$. 
not reduce $\mathrm{ETV}_{\mathrm{L}}$. Fine structural alterations in alveoli have now been somewhat improved and it is conceivable that many alveoli have been refilled with gas although the endothelial lining is still not intact and the interstitium remains grossly overloaded with fluid. The rise in FRC has now allowed pulmonary blood to be oxygenated despite the increased alveolar-capillary distance. It appears therefore that CPPV in the treatment of gross pulmonary oedema will only postpone the manifestation of oxygen deficiency by increasing oxygenation. Therefore, other forms of therapy must be instituted in order to reduce oedema.

\section{SUMMARX}

Pulmonary oedema was induced in dogs by dextran overload and the amount of fluid quantitatively assessed by using a double indicator dilution technique $\left(\mathrm{ETV}_{\mathrm{L}}\right)$. Changes in $\mathrm{ETV}_{\mathrm{L}}$ and arterial oxygenation were related to light and electron microscopic alterations of lung in early oedema and in gross oedema before and after continuous positive pressure ventilation (CPPV) was applied.

In early oedema oxygenation was only minimally impaired while there was extensive fluid accumulation in the interstitium. In late oedema oxygenation was severely reduced. At the same time alveoli were filled with plasma fluid, fibrin fibres, platelets, red blood cells and polymorphonuclear leucocytes. Endothelial cells exhibited severe injury and type II pneumocytes were also abnormal. Mast cells were found to be degranulated, which may indicate that vasoactive substances released from their cytoplasm play a role in establishing the alveolar stage of oedema. Once CPPV was applied, oxygenation improved significantly. Although alveolar fluid accumulation seemed to be somewhat less, endothelial cells still exhibited abnormalities and the interstitium remained distended by accumulated fluid.

Present results indicate that CPPV improves oxygenation in gross pulmonary oedema. As CPPV can only provide a temporary symptomatic improvement without influencing underlying pathology, it can be concluded that in gross pulmonary oedema other therapeutic measures are also required to reduce the amount of accumulated fluid in the lungs.

\section{RÉSUMÉ}

Nous avons provoqué de l'œdème pulmonaire chez des chiens en les surchargeant de Dextran, et la quantité de liquide fut évaluée par une technique de courbe de dilution $\left(E_{T} V_{L}\right)$. Les changements du $E_{T} V_{\mathrm{L}}$ et de l'oxygénation artérielle furent comparés aux perturbations de la structure pulmonaire examinée au microscope optique et au microscope électronique. Ces modifications furent étudiées dans l'œdème précoce et dans l'œè̀me important avant et après la ventilation par pression positive continue (CPPV).

Dans l'œdème précoce, les changements d'oxygénation furent minimes malgré l'accumulation d'une quantité abondante de liquide dans l'espace interstitiel. Dans l'œdème important, l'oxygénation était profondément diminuée et les alvéoles se trouvaient remplies de liquide plasmatique, de filaments de fibrine, de plaquettes, 
de globules rouges et de leucocytes polymorphonucléaires. Les cellules endothéliales montraient des lésions importantes et les pneumocytes de type il étaient également anormaux. Les mastocytes étaient dépourvus de leurs granulations, ce qui pourrait indiquer que les substances vasoactives libérées du cytoplasme de ces cellules jouent un rôle dans l'apparition de la phase alvéolaire de l'œedème. La ventilation par pression positive continue améliora l'oxygénation de façon significative. Même si l'accumulation de liquide alvéolaire semblait quelque peu diminuée, les cellules endothéliales montraient encore des anomalies et l'espace interstitiel demeurait distendu par le liquide accumulé.

Les résultats actuels indiquent que la C.P.P.V. améliore l'oxygénation dans l'œè̀me pulmonaire important. Puisque Ia C.P.P.V. ne peut apporter qu'une amélioration symptomatique et temporaire sans influencer la pathologie sousjacente, nous pouvons conclure que dans l'œdème pulmonaire important, d'autres mesures thérapeutiques sont requises pour diminuer la quantité de liquide accumulé dans les poumons.

\section{ACKNOWLEDGMENTS}

We gratefully acknowledge the expert technical assistance of Mr. Douglas Brown, Mr. Jerry Carmichael, Miss Ann Drury, Mrs. Jenepher Maine, Mrs. Donna-Joy Toelle, and Mr. Peter Wong.

Nembutal was supplied by Abbott and Dextran by Pharmacia (Canada).

This work was supported by the Medical Research Council of Canada Grant 3-501-269-20, the Ontario Thoracic Society Grant 3-333-269-11 and the Canadian Thoracic Society Grant 3-333-269-33.

\section{REFERENCES}

1. Obdrzalek, J., Kay, J. Colin, \& Noble, W. Respiratory failure in pulmonary edema. In preparation.

2. Noble, W.H. \& Severinghaus, J.W. Thermal and conductivity dilution curves for rapid quantitation of pulmonary edema. J. Appl. Physiol. 32: 770-775 (1972).

3. Noble, W.H., Obdrzalek, J., \& Kay, J.D. A new technique for measuring pulmonary edema. J. Appl. Physiol. 34: 508-512 (1973).

4. Severinghaus, J.W. Blood gas calculator. J. Appl. Physiol. 21: 1108-1116 (1966).

5. Cottrel, T.S., Levine, O.R., Senion, R.M., Weiner, J., Sprro, D., \& Fishrian, A.P. Electron microscopic alterations at the alveolar level in pulmonary edema. Circ. Res. 21: 783-797 (1967).

6. Fishman, A.P. Pulmonary edema. The water-exchanging function of the lung. Circ. Res. 46: 390-408 (1972).

7. HaAs, F. \& Bengofsky, E.H. Role of the mast cell in the pulmonary pressor response to hypoxia. J. Clin. Invest. 51: 3154-3162 (1972). 